\title{
Duch Paraklet a pamięć Kościoła w ujęciu czwartej Ewangelii
}

\author{
The Spirit-Paraclete and the Church's Memory in the Fourth Gospel
}

\author{
BRANISLAV KLUSKA \\ Catholic University in Ružomberok, Slovakia \\ branislav.kluska@gmail.com, ORCID: 0000-0003-1186-7673
}

\begin{abstract}
Streszczenie: Jezus w mowie pożegnalnej zapowiada przyjście Parakleta $(J$ 14,26), którego zadaniem będzie przypominać uczniom Jezusa to, czego ich Chrystus nauczał. Artykuł podejmuje kwestię wpływu Parakleta na pamięć uczniów i odpowiada na pytanie: Jak należy rozumieć to działanie Ducha wobec uczniów? Autor artykułu podejmuje to zagadnienie z perspektywy teologii biblijnej z uwzględnieniem elementów teorii pamięci społecznej. Najpierw przedstawia w sposób syntetyczny rozumienie pamięci w Biblii oraz podstawowe założenia teorii pamięci społecznej. Następnie analizuje tekst i dokonuje interpretacji teologicznej obietnicy Parakleta z J 14,26 oraz w świetle tych tekstów czwartej Ewangelii, w których występuje motyw pamięci $(2,17.22 ; 12,16)$. Pamięć jest bardzo ważnym elementem doświadczenia Kościoła popaschalnego. Działalność Ducha łączy teraźniejszość Kościoła z przeszłością ziemskiego Jezusa. Przedmiotem pamięci ożywianej przez Parakleta i oświecanej przez doświadczenie Zmartwychwstania są słowa Pisma oraz słowa Jezusa. Pamięć społeczna Kościoła Janowego nie jest samowystarczalna. Potrzebuje ona działania Ducha Świętego, żeby mogła być skuteczna w procesie budowania tożsamości wspólnoty.
\end{abstract}

Słowa kluczowe: Pamięć; Paraklet; czwarta Ewangelia; J 14,26; Kościół popaschalny; pamięć społeczna.

Abstract: Jesus in his farewell speech announces the sending of the Paraclete (Jn 14:26), whose task will be to remind Jesus' disciples of what Christ had taught them. The article tries to answer the question: What is a proper understanding of the Spirit-Paraclete's action upon disciples' memory? The author of the article addresses this issue from the perspective of biblical theology. First, he presents in a synthetic way the understanding of memory in the Bible and the basic assumptions of the theory of social memory. Then he analyzes the text and offers a theological interpretation of the promise of Jn 14:26 and other texts of the Fourth Gospel where a motif of remembrance is present $(2,17.22 ; 12,16)$. Memory is an essential element of the experience of the post-paschal Church. The activity of the Spirit connects the present of the Church with the past of the historical Jesus. The memory animated by the Paraclete and enlightened by the experience of the Resurrection always focuses on the words of the Scriptures and the words of Jesus. The believers' social memory within Johannine Christianity is not sufficient in and of itself, but needs the Holy Spirit's action in order to effectively build the community's identity.

Keywords: Memory; Paraclete; Fourth Gospel; John 14:26; Post-paschal Church; Social memory

Wiara w Ducha Świętego stanowi istotę tożsamości chrześcijańskiej. Po pierwsze dlatego, że wiara w Trójcę Świętą jest fundamentalną prawdą Objawienia. Po drugie z tego względu, że witalność Kościoła uzależniona jest od oddziaływania Ducha we 
wspólnocie wierzących. Ważność tej wiary sprawia więc, iż „stale winna być pogłębiana w świadomości Ludu Bożego"1.

W niniejszym artykule pragnę zgłębić rozumienie tego fragmentu czwartej Ewangelii, który opisuje szczególne działanie Ducha Świętego we wspólnocie uczniów Chrystusa. Według narracji Ewangelii zapowiada Go Jezus przed swoim pojmaniem i męką: „Paraklet, Duch święty, którego Ojciec pośle w imieniu moim, On was wszystkiego nauczy i przypomni wam wszystko, co wam powiedziałem" (J 14,26).

Wstępna lektura tego wersetu - w szerszym kontekście - wyłoniła następujące pytania: Jak należy rozumieć to działanie Ducha wobec uczniów? Dlaczego jest dla nich ważne przypominanie słów Jezusa? O jaki rodzaj przypominania chodzi?

Udzielenie odpowiedzi na te kwestie wymaga przeanalizowania obietnicy Jezusa oraz tekstów tematycznie z nią związanych (J 2,17.22; 12,16). Zanim jednak zaprezentuję analizę oraz interpretację teologiczną wspomnianych tekstów, postaram się w sposób syntetyczny przedstawić pojmowanie pamięci z perspektywy teologii biblijnej, a następnie w ujęciu teorii pamięci społecznej. Zaprezentowanie koncepcji i znaczenia pamięci w myśli biblijnej oraz miejsca i funkcjonowania pamięci w społeczeństwie (we wspólnocie Kościoła) jest ważne dla przeprowadzenia egzegezy szczegółowej tekstu J 14,26 i tekstów paralelnych.

\section{Znaczenie i funkcja pamięci w ujęciu biblijnym}

Zagadnienie pamięci podejmowane jest $\mathrm{w}$ badaniach biblijnych zasadniczo $\mathrm{z}$ dwu perspektyw: biblijno-teologicznej oraz badań nad pamięcią społeczną.

Badania prowadzone z perspektywy biblijno-teologicznej czynią przedmiotem analizy semantykę tekstów, w których występują leksemy należące do pola znaczeniowego pamięci, pamiętania lub zapominania. Często te badania nabierają kształtu opracowań leksykograficznych (np. haseł w Theologische Wörterbuch zum Alten Testament $^{2}$ czy Exegetische Wörterbuch zum Neuen Testament ${ }^{3}$ ) lub prac o charakterze syntetycznych podsumowań ${ }^{4}$.

Znamienne jest, iż w świetle tych opracowań pamięć nie jest pojmowana w kategoriach neuro-psychicznych, ale jako fenomen teologizowany. W Starym Testa-

Jan Paweł II, Dominum et Vivificantem, nr 2.

Zob. Eising, ,zākhar, zēkher, zikkārôn, 'azk'ārāh”, 64-82.

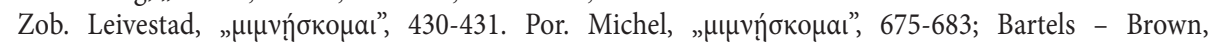
„Remember, remembrance”, 230-247.

4 Kudasiewicz, „Pamięć w Biblii”, 40-53; Smith, „Remembering God”, 631-651; Hendel, „The Exodus in Biblical Memory”, 601-622; Blair, „An Appeal to Remembrance”, 41-47; Pikor, „Rola pamięci”, 81-98. Popović, „The Bible as a Book of Memory”, 411-443; Bonnard, „Lanamnèse”, 1-11. 
mencie można - upraszczając - mówić o dwu podstawowych podmiotach pamięci - Bogu i Izraelu. W ostatniej części „Kodeksu Świętości” (por. Kpł 26,45) Bóg obiecuje pamiętać o przymierzu z Izraelem: „Przypomnę sobie na ich korzyść o przymierzu z ich przodkami”. Pamięć o przymierzu zawartym z protoplastami Izraela jest dla Boga motywem działania zbawczego wobec wszystkich ich potomków (por. zwł. Ps 105,8.42; Ps 106,45-47)5. Odpowiedzią na zbawcze, pełne miłości i charakteryzujące się wiernością względem przymierza działanie Boga jest pamięć Izraela, czego świadectwem są np. słowa Ps 105,5, w którym Izraelici są wezwani do pamięci: „Pamiętajcie o czynach, które on zdziałał". Nie chodzi przy tym o zwykłe przypominanie sobie Bożych czynów z wdzięczności, ale w grę wchodzi kwestia kształtowania tożsamości Izraela ${ }^{6}$. Pamiętanie jest niezbędne dla samej egzystencji Izraela, co podkreśla groźna przestroga w Pwt 8,19: „Lecz jeśli zapomnisz o Panu, Bogu twoim, i pójdziesz za bogami obcymi, aby im służyć i oddawać im pokłon, oznajmiam ci dzisiaj, że zginiesz na pewno". Idea pamięci jest w sposób szczególny obecna w Psałterzu oraz Księdze Powtórzonego Prawa, co potwierdzają opracowania poświęcone kwestii pamięci we wspomnianych dziełach biblijnych? ${ }^{7}$.

W Nowym Testamencie pamięć ludu Bożego też jest skierowana na zbawcze działanie Boga, które tym razem urzeczywistnia się poprzez Jezusa. Wprawdzie Nowy Testament w pewnym sensie nawiązuje do myśli Starego, gdy mówi o Bożej pamięci przynoszącej ludziom miłosierdzie i miłość (por. Łk 1,54.72) lub o tym, że Bóg przypomniał sobie jałmużny i modlitwy sprawiedliwego ( $\mathrm{Dz} 10,4)$, to jednak nowotestamentowe rozumienie pamięci nabiera nowych konotacji ${ }^{8}$. Głównym przedmiotem pamięci są słowa i czyny Jezusa (por. Dz 11,16). W badaniach teologicznych nad pamięcią uwypuklana jest zwłaszcza anamnesis, jako pamięć tradycji Kościoła, o której jest mowa w centralnym tekście anamnetycznym Nowego Testamentu - 1 Kor 11,23-26.

Badania teologiczne, aczkolwiek istotne dla zrozumienia biblijnego pojmowania pamięci, mają swoją ujemną stronę: pojmują pamięć w sposób statyczny, skupiając się prawie wyłącznie na treści, którą ona przekazuje i przechowuje.

Analizowane zjawisko jest widziane w sposób bardziej dynamiczny z socjologicznej perspektywy pamięci społecznej (pamięci zbiorowej). Choć koncepcja ta znana jest w naukach społecznych od 1925 roku, to dopiero od dwóch dekad jest

\footnotetext{
5 Por. Klusková, „Prawda o Bogu”, 208-210.

6 Pikor, „Rola pamięci”, 84; Klusková, „Prawda o Bogu”, 211.

7 Por. np.: Pavan, He Remembered; Pavan, „La memoria nel Salmo 77”, 69-90; Zenger, „Lieder der Gotteserinnerung”, 25-70; Gärtner, „From Generation to Generation”, 269-278; Blair, „An Appeal to Remembrance”, 41-47; Braulik, „Das Deuteronomium”, 9-31.

8 Por. Bartels - Brown, „Remember, remembrance”, 242.

9 Por. np. Bradshaw, „The Eucharistic Memory”, 359-370; Schröter, „Nicht nur eine Erinnerung”, 119-137.
} 
rozwijana w naukach biblijnych ${ }^{10}$. Autorem teorii pamięci społecznej jest socjolog Maurice Halbwachs, który przedstawił wyniki swoich dociekań przede wszystkim $\mathrm{w}$ pracach Le mémoir collective ${ }^{11}$ oraz Les cadres sociaux de la mémoir ${ }^{12}$ (wyd. polskie: Społeczne ramy pamięci $i^{13}$ ), zawierających podstawową tezę o odtwarzaniu przez umysł wspomnień pod presją społeczną. Koncepcja ta, zwłaszcza w ciągu ostatnich lat, zaowocowała olbrzymią liczbą prac biblijnych. Ambicją niniejszego artykułu nie jest szczegółowe przedstawienie tej teorii, lecz nakreślenie jej podstawowych cech jako pewnego hermeneutycznego punktu wyjścia dla dalszych rozważań.

Pamięć społeczna w ujęciu M. Halbwachsa nie jest mechaniczną zdolnością jednostki do rejestrowania obserwowanych zjawisk. Jest to raczej rekonstruowanie przeszłości dokonywane przez człowieka jako członka wspólnoty, dostarczającej mu pewnych ram społecznych (cadres sociaux) ${ }^{14}$. Posiada ona dwie podstawowe cechy. Po pierwsze, tworzy się przez pryzmat otoczenia socjokultorowego ${ }^{15}$. Po drugie, człowiek dzięki niej odtwarza to, co przeszłe poprzez interakcję i komunikację wewnątrz grupy społecznej (wspólnoty). W ujęciu Halbwachsa pamięć społeczna nie jest statycznym zbiorem wspomnień, ale przeżywanym ciągłym procesem kontekstualizowanym w określonych ramach społecznych ${ }^{16}$. Francuski socjolog odróżnia pamięć zbiorową od historii. O ile historia stara się podać niezmienny obraz rzeczywistości, usiłując usunąć ze wspomnień żywe i aktualizujące skojarzenia wspólnoty, dla pamięci zbiorowej właśnie owe skojarzenia stanowią podstawę istnienia. Ponadto Halbwachs odróżnia pamięć społeczną od tradycji, którą pojmuje w kategoriach zorganizowanych i zobiektywizowanych form pamięci. Tradycja jego zdaniem deformuje żywą pamięć wspólnoty. To rozróżnienie pomiędzy pamięcią i tradycją uznaje inny teoretyk pamięci społecznej, Jan Assmann, za bezpodstawne, ponieważ jego zdaniem przejście między pamięcią i tradycją jest tak płynne, że nie można wprowadzić między nie żadnej linii demarkacyjnej ${ }^{17}$.

Wyżej wspomniany egiptolog J. Assmann wraz z małżonką Aleidą w sposób znaczący rozwinęli koncepcję pamięci społecznej ${ }^{18}$. Przede wszystkim poszerzyli tę perspektywę o aspekt kulturowy. Jan Assmann zwrócił uwagę na fakt, iż pamięć kulturowa tworzy się w ciągu kilku generacji i jest poprzedzona przez pamięć zbiorową

Jeszcze w 2005 r. Alan Kirk i Tom Thacher stwiedzili, iż „it is surprising that social memory has, as yet, made no significant impact on Biblical Studies”. Kirk, „Jesus Tradition as Social Memory”, 25.

11 Zob. Halbwachs, Le mémoire collective.

12 Zob. Halbwachs, Les cadres sociaux de la mémoire.

13 Zob. Halbwachs, Społeczne ramy pamięci.

14 Zob. Halbwachs, Społeczne ramy pamięci, 178.

15 Społeczeństwo jest podmiotem utrwalającym i przechowującym podstawowe wartości oraz prawdy religijne i kulturowe. Por. Almášiová, Sociológia, 61-68, 87-93.

17 Zob. Assmann, Pamięć kulturowa, 61.

18 Zob. np. Assmann, Pamięć kulturowa; Assmann, Religion und kulturelles Gedächtnis; Assmann, Erinnerungsräume. 
żyjącej wspólnoty. Niemiecki uczony nazwał ten rodzaj pamięci pamięcią komunikatywną (komunikatives Gedächnis) ${ }^{19}$. Trwa ona przez dłuższy okres - od osiemdziesięciu do stu lat. To jest czas, w którym jednocześnie żyje obok siebie kilka generacji, między którymi dochodzi do wymiany doświadczeń i wspomnień członków wspólnoty ${ }^{20}$. Po tym okresie pamięć komunikatywna wygasa, dochodzi do zerwania tradycji (Traditionsbruch). Ma szansę przetrwać jedynie wtedy, gdy zmieni się w pamięć kulturową i zostanie utrwalona. Do tego przyczynia się istnienie pisma, które umożliwia tekstualizację pamięci. Pamięć zbiorowa scala fragmentaryczne wspomnienia poprzedniej pamięci w całościowe opowiadania, mity oraz legendy o strukturze narracyjnej ${ }^{21}$.

Koncepcje M. Halbwachsa oraz J. Assmanna zostały zastosowane w biblistyce ${ }^{22}$, zwłaszcza w badaniach nad kształtowaniem pamięci społecznej Izraela ${ }^{23}$, nad Jezusem historycznym ${ }^{24}$, nad przekazem tradycji oralnej $j^{25}$ oraz tożsamości wspólnotowej kształtowanej przez pamięć społeczną ${ }^{26}$. Koncepcja pamięci społecznej została zastosowana również w badaniach nad czwartą Ewangelią. Zasługi na tym polu należy przypisać zwłaszcza Tomowi Thacherowi² ${ }^{27}$, który jednak skupił się wyłącznie na kwestii funkcji pamięci w procesie kompozycji narracji czwartej Ewangelii. Za słabą stronę jego badań uważam również to, że analizom poza-tekstualnym poświęcił zdecydowanie więcej uwagi niż badaniu tekstu Ewangelii. Jego analizy tekstu biblijnego są ponadto pobieżne i asocjatywne oraz całkowicie podporządkowane kategoriom socjologicznym. W badaniach nad czwartą Ewangelią nie pojawiła się jak

19 Zob. Assmann, „Das kulturelle Gedächtnis”, 239-247.

20 Po upływie mniej więcej połowy tego czasu świadkowie jakiegoś ważnego wydarzenia wkraczają w wiek, w którym staje się dla nich konieczne przekazanie wspomnień innym członkom wspólnoty, inaczej ich pamięć nie przetrwa.

21 Zob. Assmann, Pamięć kulturowa, 108-110.

22 Zarówno Maurice Halbwachs, jak również Jan Assmann w swoich badaniach uwzględnili zagadnienie pamięci społecznej biblijnego Izraela oraz pierwotnego Kościoła. Por. Halbwachs, Społeczne ramy pamięci, zwłaszcza rozdz. VI: „Pamięć zbiorowa grup religijnych” (262-323). Por. także Assmann, Pamięć kulturowa, rozdz. V: „Izrael i wynalezienie religii” (210-241). Maurice Halbwachs starał się przenieść wyniki swoich badań również na teren pierwotnego chrześcijaństwa. Por. Halbwachs, La Topographie légendaire des évangiles. Znaczący jest fakt, iż w dziele tym praktycznie ignoruje on ówczesną wiedzę biblijną. Swoje rozumienie Ewangelii opiera na jedynym dziele Ernesta Renana.

23 Por. np. Blenkinsopp, „Memory, Tradition”, 76-82; Smith, „Remembering God”, 631-652; Smith, The Memoirs of God.

24 Por. np.: Byrskog, „A New Quest”, 319-336; Foster, „Memory, Orality”, 191-227; Keith, „Memory and Authenticity”, 155-177; Gregory, „Memory as Method”, 52-61; Keith, „The Narratives of the Gospels”, 426-555. Według Sandry Hübenthal „The only area in biblical research where social memory theory has gained reasonable currency is historical Jesus research and even there is treated highly critically and discussed extremely controversially”. Hübenthal, „Social and Cultural Memory”, 192.

25 Por. Eve, „Memory, Orality”, 311-333; Keith, „Social Memory Theory”, 519-525.

26 Por. Guijarro, „Cultural Memory”, 90-100.

27 Por. Thatcher, „John's Memory Theater”, 487-505; Le Donne - Thatcher, The Fourth Gospel; Thatcher, Why John Wrote a Gospel. Por. również: Le Donne, „Memory, Commemoration”, 186-206; Vouga, „Erinnerung an Jesus”, 28-37; Eckstein, „Das Johannesevangelium”, 299-319; Frey, „The Gospel of John”, 261-284. 
dotąd żadna publikacja, w której koncepcja pamięci społecznej byłaby zastosowana do odczytania funkcji Parakleta oddziaływującego na pamięć wspólnoty Janowej. W niniejszym opracowaniu autor postara się przedstawić Janową koncepcję pamięci, odwołując się do pewnych elementów koncepcji pamięci zbiorowej, świadomy tego, iż w ramach tego typu publikacji nie będzie mógł rozwiązać problemu w sposób wyczerpujący.

\section{Znaczenie i istota działania Parakleta na pamięć uczniów}

Przypominanie słów Jezusa Jego uczniom jest ważnym zadaniem Parakleta, zapowiedzianym w 14,26: „Paraklet, Duch święty, którego Ojciec pośle w imieniu moim, On was wszystkiego nauczy i przypomni wam wszystko, co wam powiedziałem". Obietnica ta zawarta jest $\mathrm{w}$ drugiej mowie o Paraklecie (w. 25-26) w ramach pierwszej mowy pożegnalnej (J 14,1-31)28. Główna część mowy (w. 4-27ab), skoncentrowanej na tematyce odejścia Jezusa, obramowana jest wprowadzeniem (w. 1-3) oraz podsumowaniem (w. 27c-31) ${ }^{29}$. Jezus odchodzi od swoich uczniów, którzy tylko dzięki wierze mogą przyjąć i zrozumieć Jego odejście (w. 4-14). Zapowiada swój powrót do tych, którzy w Niego uwierzyli i którzy w miłości oraz wierności Jego przykazaniom są w stanie przyjąć Parakleta, Jego i Ojca. Ponowna obecność Mistrza w uczniach odróżnia ich od świata (por. w. 15-27ab). Od wersetu 15 nacisk zostaje położony na miłość uczniów, która razem $\mathrm{z}$ wiarą wyakcentowaną w wersetach 1-14, stanowi antidotum na przeżywany kryzys ${ }^{30}$. Konkretnym przejawem miłości jest zachowywanie przykazań Jezusa. Kochający uczeń, który zachowuje przykazania Jezusa, jest zdolny

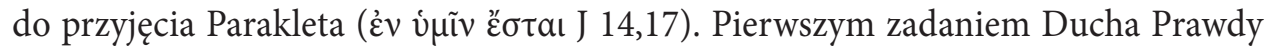
jest obecność (w. 16), drugim - nauczanie i przypominanie (w. 26).

Mowy pożegnalne od strony formalnej i treściowej stanowią zwartą jednostkę literacką, pełniącą w narracji czwartej Ewangelii wyjątkową rolę. Udo Schnelle w swoim artykule („Die Abschiedsreden im Johannesevangelium”, 64) pisze: „die Abschiedsreden sind ein Schlüsseltext für die Beurteilung der literarischen Struktur und der theologischen Intention des 4. Evangeliumsgeliums".

Por. szczegółową analizę struktury tzw. pierwszej mowy pożegnalnej (J 14,1-31) oraz przedstawienie różnych jej ujęć: Kluska, Uczeń ikoną Chrystusa, 129-141.

Warto wspomnieć w tym miejscu o dwóch opracowaniach, które w sposób szczegółowy zostały poświęcone Sitz im Leben mowy pożegnalnej Jezusa (J 14,1-31). Dla obu punktem wyjścia ich analiz jest problem odejścia Jezusa, na które Jego uczniowie reagują nieporozumieniem. Według Johna Paintera problem ten odzwierciedla późniejszą sytuację wspólnoty Janowej, przeżywającej trudności związane z niespełnionym oczekiwaniem szybkiej Paruzji. Zob. Painter, „The Farewell Discourses”, 525-543. Inną rekonstrukcję Sitz im Leben tekstu przedstawia Fernando F. Segovia, który wskazuje na kryzys wiary wspólnoty Janowej. Zob. Segovia, „The Structure, Tendenz”, 471-493. Moim zdaniem te dwa podejścia są komplementarne, bowiem wiara zostaje podważona i zachwiana na skutek nieodczuwalnej obecności Mesjasza. Chrześcijanie żyjący w czasach post-paschalnych mogli bardzo intensywnie przeżywać tę absencję osoby Jezusa w swoim życiu, zwłaszcza w zderzeniach ze światem niewierzącym. 
Wspólnota Janowa, której sytuację egzystencjalną odzwierciedla mowa pożegnalna (14,1-31), pogrążona jest w kryzysie wywołanym przez nieobecność Jezusa. Tekst mowy jest obramowany podwójnym wezwaniem „niech się nie trwoży wasze serce” (14,1.27). Przytoczona inkluzja podkreśla funkcję pragmatyczną dyskursu, który rozwija pewną strategię względem wspólnoty. Tę strategię można według koncepcji socjologicznej Bryana Wilsona ${ }^{31}$ określić jako scenariusz introwersji wspomagany przez taumaturgiczną strategię $e^{32}$. Argumentacja introwersji obrazuje wspólnotę zwróconą do wewnątrz, zmagającą się z własnym zachwianiem wiary i z niezrozumieniem słów Jezusa. W mowie pożegnalnej uczniowie Jezusa: Piotr (13,36a.37), Tomasz $(14,5)$ i Filip $(14,8)$, po kolei wykazują się wielkim stopniem niezrozumienia Jego odejścia. W reakcji na to Jezus wzywa ich do wiary $(14,11)$, bowiem tylko wiara w Niego i w Jego jedność z Ojcem może przezwyciężyć to niezrozumienie. Wiara jest warunkiem doświadczenia obecności Jezusa. Wiara razem z akceptacją przykazań $(14,21)$ prowadzą do jedności ucznia z Jezusem i Jego Ojcem. Wiara i miłość są podstawowymi wartościami, na których ma się opierać alternatywne społeczeństwo Janowe $e^{33}$, przeżywające swoją odrębność od otaczającego go świata $(14,17.22)$. Członkowie wspólnoty Janowej mogą jednak liczyć na pomoc i bliskość świata nadprzyrodzonego, co podkreśla taumaturgiczna argumentacja dyskursu. Jezus bowiem obiecuje uczniom nowy sposób obecności - duchową bliskość - przede wszystkim poprzez swoje powtórne przyjście $(14,3.18)$, obietnicę wspólnego przebywania w domu Ojca (14,2-3), niepowtarzalną jedność uczniów z Ojcem i Synem $(14,20.23)$ oraz obietnicę Parakleta, Ducha Świętego, Ducha Prawdy (14,16-17.26-27), którego zadaniem będzie specyficzne oddziaływanie na pamięć uczniów. Taumaturgiczna strategia dyskursu pokazuje, iż wpływu Parakleta na pamięć uczniów nie należy rozumieć w kategoriach naturalnego porządku, chociaż pamiętanie, przypominanie ze swojej istoty należą do takiego właśnie naturalnego czy - mówiąc ściślej - neuropsychicznego, biologicznego lub socjologicznego porządku. Poprzez działanie Parakleta na pamięć uczniów nadprzyrodzone, boskie działanie jest doświadczalne we wspólnocie Janowej.

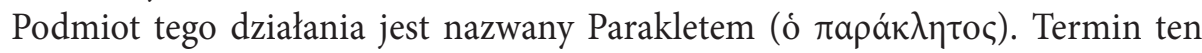
występuje w Nowym Testamencie tylko w pismach Janowych (J 14,16.26; 15,26; 16,7; $1 \mathrm{~J} 2,1$ ). W Pierwszym Liście św. Jana odnosi się on do Chrystusa, natomiast w czwartej Ewangelii jest to określenie Ducha Świętego $(14,26)$, nazywanego też Duchem

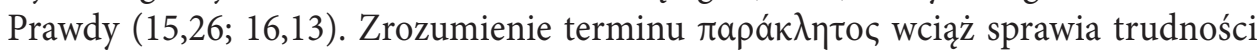
egzegetom i tłumaczom. Znaczenia tego greckiego rzeczownika nie można oddać

31 Por. Wilson, Magic and the Millennium, 22-26. Dla potrzeb interpretacji biblijnej zaadaptował tę koncepcje Vernon Robins. Por. Robbins, The Tapestry of Early Christian Discourse, 147-159.

32 Prezentacje konkretnych strategii dyskursu w tym ujęciu zob. Kowalski, „Retoryka i socjo-retoryka”, 125126.

33 "John writes for persons actually living in an alternate society embedded in a larger society - the society of «this world» and of «Judeans»”. Malina - Rohrbaugh, Social-Science Commentary, 15. 
jednym słowem, dlatego tłumacze często decydują się nie stosować konkretnego odpowiednika, lecz zachowują oryginalne brzmienie terminu, dostosowując go do wymogów gramatycznych konkretnego języka ${ }^{34}$.

Wbrew licznym analizom i badaniom wciąż nie jest jasna ani wartość semantyczna tego terminu, ani zakres funkcji, którą postać Parakleta miałaby pełnićn ${ }^{35}$. Najczęściej wymieniane są następujące funkcje: sądownicza (obrońcy i oskarżyciela), orędownika, mądrościowa oraz pośrednika (w interpretacji antropologii kulturowej) ${ }^{36}$. Ponieważ celem niniejszego artykułu nie jest rozstrzygnięcie problemu funkcji Parakleta w sposób absolutny, skupię się tylko na przedstawieniu jego funkcji opisanej w J 14,26.

Zadanie, jakie Paraklet ma pełnić wobec uczniów, jest określone przy pomo-

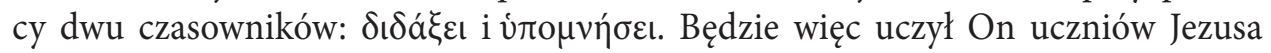

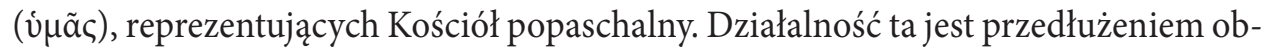
jawicielskiej działalności Jezusa, która została zainicjowana przez Ojca i w Nim ma swe źródło. Parakleta pośle ( $\pi \varepsilon \dot{\varepsilon} \mu \psi \varepsilon \iota)$ Ojciec. Czasownik $\pi \dot{\varepsilon} \mu \pi \omega$ odnosi się w czwartej Ewangelii przede wszystkim do misji Jezusa posłanego przez Ojca (zob. np. 14,24). W posłaniu Parakleta uwidacznia się kontynuacja dzieła Jezusa, które nie skończy się wraz z kresem Jego działalności ziemskiej. Łączność Ducha z Jezusem i Jego misją jest podkreślona również przez fakt, iż Duch święty będzie posłany przez Ojca

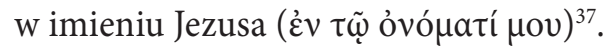

W kontekście analizowanego wersetu właściwe znaczenie czasownika $\delta ı \delta a \sigma \kappa \varepsilon \tilde{v}$ najbardziej oddaje słowo „objawiać”. Jezus uczył świat tego, co usłyszał od Ojca

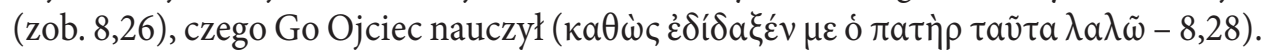
Paraklet staje się częścią „łańcucha” Objawienia ${ }^{38}$. Duch święty kontynuuje Objawie-

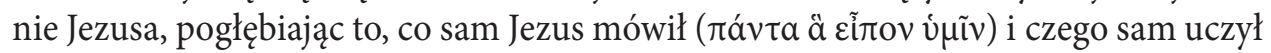
(por. 7,16) ${ }^{39}$. Ważnym tłem religijnym dla czwartej Ewangelii może być tradycja sapiencjalna, według której personifikowana mądrość naucza (Mdr 8,7; 9,17-18)

Czynność nauczania, której podejmuje się Paraklet, dookreślona została w dalszej części zdania za pomocą czasownika „przypomni” (نં na naturalnym poziomie, pamięć jest kluczowym elementem w procesie uczenia. Tak było w kulturze żydowskiej, jak również w środowisku grecko-rzymskim. Pamięć odnoszona do Objawienia podkreśla jego historyczny charakter. Ścisły zwią-

\footnotetext{
34 Por. Brown, John XIII-XXI, 1137; Jankowski, „Paraklet”, 183-206.

35 Por. Kluska, Uczeń ikona Chrystusa, 298; Brown, Spirit in the Writings of John, 62-74.

36 Por. Lapko, Jánovo evanjelium, 127; Brown, Spirit in the Writings of John, 62-74; Dąbek, „Przywołany Posłany - Obecny”, 17-21; Witczyk, „Paraklet”, 77-91.

"Joh betrachtet die Sendung des Geistes in gewisser Weise als Fortsetzung der Sendung des Sohnes" (Schnackenburg, Das Johannesevangelium 13-12, 95).

Por. Keener, The Gospel of John, 977-978.
} 
zek między pamięcią i nauczaniem wskazuje na to, iż przypominanie przeszłości nie jest „pomocą” dla zawodnej pamięci, lecz staje się odnową, aktualizacją tego, co się wydarzyło, tak żeby słowa Jezusa wypowiedziane w przeszłości stawały się ciągle aktualnym nauczaniem, z którego nic się nie straci (por. dwa razy powtórzone $\pi a ́ v \tau a$ - 14,26). Paraklet „przywraca” naukę Jezusa, który jest już w sposób cielesny nieobecny. Naukę, którą Jezus przyniósł człowiekowi, Duch podejmuje, podaje i naucza, wprowadza ją do serca i umysłu ucznia ${ }^{41}$.

W kontekście koncepcji pamięci społecznej należy w pierwszej kolejności zwrócić uwagę na fakt, iż adresatem działania Parakleta jest wspólnota uczniów. Nie jest nim wybrana jednostka, np. uczeń umiłowany, ale grupa społeczna wierzących w Chrystusa. Wspólnota ta nie jest zdolna do generowania pamięci, ale jest zdana na działanie Parakleta. Jej (nie)działanie wymyka się modelom zachowania grup społecznych znanym z koncepcji pamięci zbiorowej/społecznej. Charakterystycznym jest również fakt, iż obietnica działania Parakleta na pamięć uczniów jest do nich skierowana w kontekście zapowiedzi odejścia Jezusa (Jego śmierci). W ujęciu J. Assmanna śmierć jest najbardziej podstawową formą doświadczenia zerwania ciągłości. Staje się w ten sposób początkiem i główną przestrzenią kształtowania kultury pamięci. Troska grupy o to, by osoba dla niej ważna (jej dzieło lub doświadczenie) nie została zapomniana, jest procesem przeradzającym się w żywe pamiętanie ${ }^{42}$. W ujęciu Ewangelii Janowej to jednak nie grupa troszczy się o zachowanie pamięci, ale sam Jezus zapewnia kontynuatora swojej pamięci dla wspólnoty.

W starożytnych kulturach można spotkać się z rodzajem pamięci perspektywnej, gdy pewne osoby już za życia zapewniały sobie pamięć o swoich sławnych czynach. W tym celu na przykład władcy egipscy budowali grobowce ${ }^{43}$. Jezus w jakimś sensie też zapewnia sobie perspektywę trwania pamięci, lecz nie chodzi przy tym o jej materialne udokumentowanie, lecz o żywe, osobowe, a zarazem nadprzyrodzone przypominanie.

Z tekstu czwartej Ewangelii wynika pewna słabość wspólnoty, która potrzebuje działania Ducha, żeby nie utracić niczego ze skarbu objawienia (por. wyakcentowane

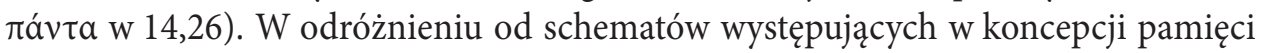
społecznej (zwłaszcza w nieco pozytywistycznym ujęciu M. Halbwachsa ${ }^{44}$ ) wspólnota uczniów nie jest wszechmocna w procesie budowania pamięci. Nie jest nawet całkiem autonomiczna. Jeżeli ma przetrwać pamięć o słowach Jezusa, wspólnota musi być otwarta na działanie Parakleta.

\footnotetext{
Zob. Ferraro, Il Paraclito, Cristo, il Padre, 64.

Por. Rajewski, „Rozważania na temat Assmanowskiej teorii pamięci”, 201.

Por. Assmann, Pamięć kulturowa, 184-189.

Por. krytykę pozytywizmu Mauriciego Halbwachsa: Keith, „Social Memory Theory”, 362-363.
} 


\section{Pamięć uczniów w popaschalnym okresie Kościoła}

Działalność Ducha Parakleta wyznaczona jest na okres nieobecności Jezusa, na popaschalny okres Kościoła, który jest właściwym okresem działania Ducha Świętego we wspólnocie Kościoła. O takiej właśnie sytuacji, kiedy uczniowie, dzięki ożywionej pamięci, są w stanie głębiej zrozumieć nauczanie Jezusa, jest mowa w dwóch tekstach czwartej Ewangelii (J 2,22; 12,16).

Pierwszy tekst, w którym zawarta jest idea pamięci, to komentarz narratora, zamykający epizod oczyszczenia świątyni (J 2,13-22). W czwartej Ewangelii znajduje się na samym początku opisu publicznej działalności Jezusa, co dodaje mu ważności i podkreśla jego programowy charakter ${ }^{45}$.

Epizod opisujący oczyszczenie świątyni składa się z dwóch części: pierwsza część (w. 13-17) przedstawia sam czyn Jezusa, druga (w. 18-22) jest wyjaśnieniem tego czynu. Warto zauważyć, iż obie części zakończone są komentarzem narratora o refleksji uczniów - najpierw nad czynem Jezusa, a następnie nad Jego słowami. W obu przypadkach podstawą refleksji jest pamięć uczniów ${ }^{46}$.

Całe wydarzenie rozgrywa się w kontekście zbliżającego się święta Paschy ${ }^{47}$. Właśnie w tym świetle należy odczytywać sens czynów i słów Jezusa. Jezus przybywający do Jerozolimy natychmiast udaje się do świątyni. Ewangelista określa ją greckim terminem i̊póv, pod którym kryje się cały kompleks budowli i dziedzińców ${ }^{48}$. Narrator stwierdza, że w świątyni Jezus zastaje sprzedających woły, baranki i gołębie, oraz bankierów wymieniających monety potrzebne do zapłacenia podatku świątynnego. Jezus w pełny oburzenia sposób - używając bicza - wypędza wszystkich z świątyni. Do sprzedawców gołębi mówi: „Nie róbcie z domu mego Ojca targowiska!” $(2,16)$. Wypowiadając te słowa, dokonuje bardzo ważnej zmiany. Nie nazywa już świątyni

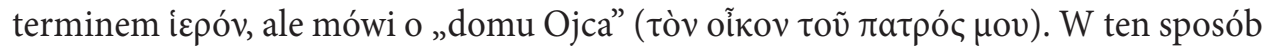
wyraża, że świątynia nie jest tylko miejscem dla celebracji kultycznych, ale przestrzenią, gdzie Bóg Izraela - którego Jezus nazywa swoim Ojcem - ma swój przybytek ${ }^{49}$. Krytyczne nazwanie świątyni „domem targowiska” (oĩ אov દ̇ $\mu \pi$ róíov) jest aluzją do starotestamentowej zapowiedzi proroka Zachariasza "nie będzie w owym dniu przekupnia w domu Pana zastępów" (Za 14,21).

W świetle Starego Testamentu czyn Jezusa interpretują początkowo również Jego uczniowie. Narrator zaznacza, iż przypomnieli sobie oni ( $\dot{\mu} \mu \eta \dot{\sigma \theta} \theta \sigma \alpha v)$

\footnotetext{
45 Zob. Brown, John I-XII, 116-120.

46 Zob. Wengst, Das Johannesevangelium 1-10, 120. Por. Schenke, Johannes, 60-61; Gnilka, Johannesevangelium, 24.

47 Klaus Wengst (Wengst, Das Johannesevangelium 1-10, 120) zwraca uwagę na fakt, iż jest to pierwsza $\mathrm{z}$ trzech pasch. Ostatnia $\mathrm{z}$ nich, która jest zwieńczona śmiercią i zmartwychwstaniem Jezusa, nadaje pasyjne rozumienie wszystkim paschom wspomnianym w czwartej Ewangelii.

48 Zob. Trstenský, Svet Nového zákona, 115. Popowski, Wielki słownik grecko-polski, 297.

49 Zob. Moloney, Belief in the Word, 97; Lapko, Jánovo evanjelium, 24.
} 
słowa Ps 69,10. Tekst ten, opisujący lamentację cierpiącego człowieka, powstał prawdopodobnie krótko po niewoli babilońskiej, w kręgu grupy ludzi starających się o odbudowę świątyni ${ }^{50}$. Dla uczniów czyn Jezusa jest więc pewną próbą rekonstrukcji świątyni i jej kultu. Znamienna jest drobna zmiana w stosunku do Ps 69,10. W tekście

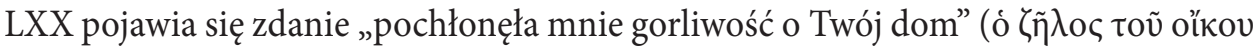

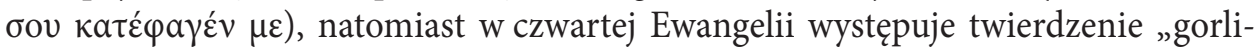

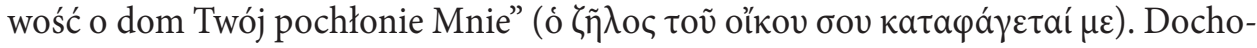

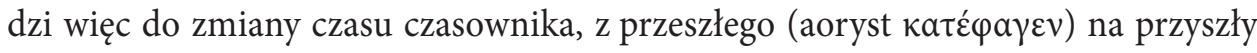

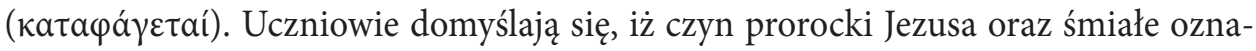
czenie świątyni jako dom Ojca doprowadzą ich Nauczyciela do zagłady ${ }^{51}$. Pamięć uczniów pozostaje jeszcze w obrębie Starego Testamentu, ponieważ pojmują oni Jezusa w kategoriach starotestamentowych postaci gotowych poświęcić swoje życie dla czci Boga, jak np. Pinchas, Eliasz albo Matatiasz (Lb 25,11; 1 Krl 19,10.14; Sir 48,2; 1 Mch 2,24-26) ${ }^{52}$. Pamięć uczniów Jezusa, jako prawdziwych Izraelitów, skupiona jest na kluczowych wydarzeniach i postaciach dziejów zbawienia Starego Testamentu. Te, co prawda, zaczynają odczytywać w świetle osoby Jezusa, nie są jednak zdolni wyjść poza ten obręb.

Wyjaśnienie czynu Jezusa inicjują żydzi (oi 'Iov反aĩol) ${ }^{53}$, żądający od Niego znaku ( w świątyni $(2,18)$. Jezus odpowiada im w sposób prowokacyjny. Żydzi domagali się od niego nowego czynu, a On pobudza ich do działania, które jest niewyobrażalne.

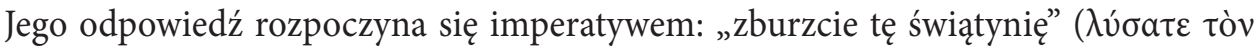
vaòv). Jezus stosuje teraz grecki rzeczownik vaó ${ }^{54}$, który w Nowym Testamencie używany jest do określenia najbardziej wewnętrznej części w świątyni, nazywanej „miejscem najświętszym”, będącym miejscem obecności Boga.

Druga część odpowiedzi Jezusa skupia się na Nim samym. Jezus zapowiada, że miejsce obecności Boga odbuduje w trzy dni. Słowa Jezusa są niewątpliwie zaskaku-

50 Według Norberta Tillmana (Das Wasser bis zum Hals!) w tekście można rozpoznać trzy etapy powstawania psalmu. Wiersz 10 należy do drugiego etapu, odzwierciedlającego sytuację wspólnoty po powrocie z wygnania babilońskiego. Według Milana Sovy wiersz ten przedstawia sytuację proroka Jeremiasza, który był znany z krytyki kultu w Jerozolimie. Zob. Hroboň, Žalmy 51 - 75, 509. Według Gianfranco Ravasiego (Il libro dei salmi, 419) możliwym kontekstem tych słów jest sytuacja proroka Aggeusza przed rozpoczęciem odbudowy świątyni albo sytuacja Nehemiasza borykającego się z problemami i intrygami w społeczeństwie repatriantów.

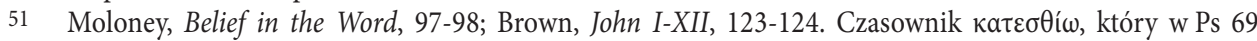
ma znaczenie „pochłaniać przez gorliwość, uzyskuje w J 2,17 nową konotację, mianowicie "pożerać, „niszczyć, „,spowodować zgon”, która w Ps 69 jest wprawdzie możliwa, ale mało nieprawdopodobna. Por. Hroboň, Žalmy $51-75,509$.

52 Por. Moloney, Belief in the Word, 98.

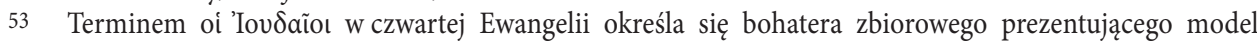
odrzucenia Objawienia. Zob. Wróbel, „Historia i teologia”, 127-128; Culpepper, Anatomy of the Fourth Gospel, 125-132.

54 Zob. Trstenský, Svet Nového zákona, 117. Popowski, Wielki słownik grecko-polski, 407. 
jące, zwłaszcza ze względu na stopień hiperbolizacji. Ta zaś, razem z symbolicznym wyrażeniem „,w trzy dni”, jest wskaźnikiem, iż zdania Jezusa nie należy rozumieć w sposób dosłowny. Jednak dokładnie tak zrozumieli je żydzi, wyrażający swoje zdziwienie w słowach: „Czterdzieści sześć lat budowano tę świątynię, a Ty ją wzniesiesz w przeciągu trzech dni?” Wypowiedź ta ma formę pytania retorycznego zamykającego dyskusję oraz wyraża odrzucenie Jezusa ${ }^{55}$.

Po ripoście żydów następują dwa komentarze narratora. Pierwszy wyjaśnia właściwy sens słów Jezusa: „On zaś mówił o świątyni swego ciała” (w. 21). Należy podkreślić, iż tutaj narrator nie powtarza rzeczywistych słów Jezusa, ale przytacza ich głębszy, pełniejszy sens. Na poziomie narracji czytelnik otrzymuje wyjaśnienie ${ }^{56}$, do którego jednak uczniowie muszą dojrzeć.

W drugim komentarzu narrator skupia się na reakcji uczniów: „Gdy więc zmartwychwstał, przypomnieli ( $\dot{\mu} \mu \eta \dot{\sigma} \sigma \eta \eta \sigma \alpha)$ sobie uczniowie Jego, że to powiedział, i uwierzyli Pismu i słowu, które wyrzekł Jezus" (J 2,22). Znamienny jest fakt, iż narrator nie mówi o natychmiastowej reakcji, ale o responsie z wyraźnym czasowym odstępem. Momentem przełomowym jest zmartwychwstanie Chrystusa. Uczniowie Jezusa trwają więc w braku pełnego rozumienia aż do momentu Jego wskrzeszenia. Jedynie godzina śmierci i zmartwychwstania umożliwią podniesienie ich wiary na wyższy poziom, ale do tego jest potrzebna ich pamięć. Co jednak wytworzyła pamięć uczniów: słowa Jezusa wypowiedziane podczas wydarzenia czy ich głębsze znaczenie? Uważne śledzenie narracji pokazuje, że właśnie to pogłębione rozumienie. Pamięć uczniów nie ma charakteru odtwórczego, ale kreatywny. Nie chodzi tylko o przypominanie, ale o głębszą (re)interpretację słów Jezusa.

Drugim tekstem, który mówi o pamięci uczniów w kontekście popaschalnym, są słowa narratora $(J$ 12,16) komentującego akt zapamiętywania, odnoszący się do wydarzenia uroczystego wjazdu Jezusa do Jerozolimy (12,12-15). Dygresja narratora zamyka to opowiadanie. Wydarzenie to, podobnie jak w poprzedniej narracji, ma miejsce w kontekście święta Paschy $(12,1)$. Jest to ostatnia Pascha Jezusa, która zostanie zwieńczona Jego śmiercią i zmartwychwstaniem. Cały rozdział $12 \mathrm{w}$ narracji czwartej Ewangelii stanowi swoisty pomost: opisuje zakończenie publicznej działalności Jezusa, a zarazem przesuwa uwagę czytelnika na drugą część Ewangelii (rozdz. 13-21), objawiającą prawdziwą chwałę Mesjasza ${ }^{57}$. Po opisie namaszczenia w Betanii, implikującego pogrzeb Chrystusa (12,1-8), przedstawione zostały dwie postawy ludzi wobec Jezusa - nieprzychylna postawa arcykapłanów reprezentujących wrogi świat

55 Por. Moloney, Belief in the Word, 101.

56 Por. Feník, „Ježišova telesnost”, 77.

57 Zdaniem Klausa Scholtisseka tekst J 11,55-12,50 jest bardziej spójny od strony treściowej oraz narracyjnej z drugą częścią ewangelii (J 13-21) niż z pierwszą (J 1-12). Biblista argumentuje: „Am treffendsten ist daher von einer Brückenfunktion der Kapitel 11 und 12 zwischen dem ersten Hauptteil in 1,18-10,42 und dem zweiten in 13,1-20,29 zu sprechen”. Scholtissek, „Abschied und neue Gegenwart”, 334. Por. Mlakuzhyil, The Christocentric Literary Structure, 415. 
i postawa tłumu przyciągniętego nie tyle właściwą wiarą w Jezusa, ile szukającego sensacji. Opis wjazdu do Jerozolimy w czwartej Ewangelii jest wprawdzie spokrewniony z opisami znanymi z ewangelii synoptycznych, ma jednak własną perspektywę teologiczną $a^{58}$.

Cały jest zdominowany przez motyw królewski - ewangelista powoli przygotowuje czytelnika na moment objawienia prawdziwej królewskiej godności Jezusa podczas Jego męki. Tłum pielgrzymów przybyłych do Jerozolimy na święto wychodzi naprzeciw przychodzącemu Jezusowi. Pielgrzymi witają Go jako króla wjeżdżającego do miasta, o czym świadczą przede wszystkim gałązki palmowe (por. 2 Mch 14,4) oraz zastosowany tytuł "król Izraela” dodany do inwokacji Psalmu 118. Motyw ga-

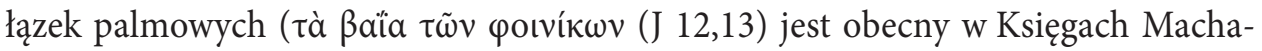
bejskich (1 Mch 4,36-59; 13,51; 2 Mch 10,6-7) w kontekście opisów walki żydów o niepodległość. Obraz tych gałązek najprawdopodobniej funkcjonował jako pewien symbol mesjanizmu nacjonalistycznego. Dlatego tłum witający Jezusa z gałązkami w ręku narzuca na Jezusa swoje oczekiwania polityczne. W pragnieniu ludzi jest On tym, kto naśladuje Machabeuszy w zmaganiu $\mathrm{z}$ okupantem ${ }^{59}$.

W tym momencie dochodzi jednak do nieoczekiwanej zmiany - Jezus jakby przez przypadek ${ }^{60}$ znajduje osiołka i siada na niego. Ten czyn jest interpretowany w świetle tekstu Za 9,9. Brzmienie cytatu występującego w J 12,15 jest określone zamiarami teologicznymi autora czwartej Ewangelii ${ }^{11}$ i podkreśla godność Jezusa jako mesjańskiego króla pokoju przynoszącego zbawienie ${ }^{62}$. W ten sposób Jezus pokazuje, iż jego rozumienie królewskości odległe jest od oczekiwań tłumu.

Narrator przedstawia niezrozumienie nie tylko tłumu pielgrzymów, ale również

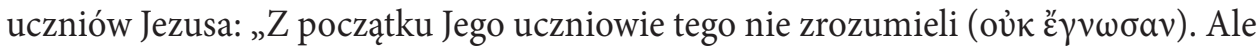
gdy Jezus został uwielbiony, wówczas przypomnieli sobie ( $\dot{\varepsilon} \mu \eta \dot{\sigma \theta} \theta \sigma \alpha v)$, że to o Nim było napisane i że tak Mu uczynili” $(12,16)$. Uczniowie przez cały czas pozostają cichymi obserwatorami wydarzenia, nie podejmują żadnych działań. Na razie nawet nie rozumieją prawdziwego sensu tego, co się dzieje. Doświadczenie empiryczne faktów i poznanie słów Pisma, na które wskazuje czasownik $ү ı \omega \omega \sigma \kappa \omega$, jest dla uczniów niewystarczające.

Ewangelista podkreśla, iż uczniowie zrozumieli sens tego, co nastąpiło dopie-

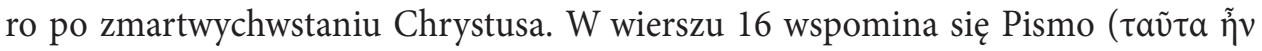

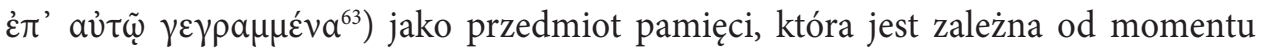
zmartwychwstania Jezusa. Potrzebne jest więc wydarzenie zmartwychwstania, żeby

\footnotetext{
58 Zob. Gnilka, Johannesevangelium, 98. Beutler, Das Johannesevangelium, 353-354.

59 Zob. Kubiś, The Book of Zechariah, 104-105.

60 Zob. Gnilka, Johannesevangelium, 150.

61 Cytat Za 9,9 został przez autora czwartej Ewangelii skrócony oraz zmieniony w początkowej części. Por. szczegółową analizę zmian oraz ich motywacji semantycznej: Kubiś, The Book of Zechariah, 75-86.

62 Zob. Kubiś, The Book of Zechariah, 104-105.

63 Zaimek $\tau a \tilde{\tau} \tau a$ niewątpliwie wskazuje na cytat Za 9,9 przytoczony w poprzednim wierszu.
} 
uczniowie osiągnęli pełne zrozumienie Pisma. Relewantnym jest również fakt, iż całe wydarzenie ma miejsce w kontekście święta Paschy, które dla żydów było szczególną okazją do przypominania sobie wydarzeń zbawczych Starego Testamentu. Autor czwartej Ewangelii pokazuje, iż teraz staje się ono okazją do pamięci o Chrystusie oraz do przypominania sobie słów Pisma w sposób chrystocentryczny.

Teoria pamięci społecznej podkreśla na pierwszym miejscu wkład wspólnoty w proces zapamiętywania. W obu epizodach z czwartej Ewangelii podmiotem pamiętania byli bliżej nieokreśleni uczniowie w okresie popaschalnym. Ramy społeczne Kościoła stały się więc podstawowym kontekstem pamięci. Mając na względzie temat niniejszego artykułu należy przyznać, iż w epizodach tych nie pojawia się postać Parakleta oraz nie mówi się w sposób bezpośredni o działaniu Ducha. Jednak z powodu ścisłego połączenia śmierci i zmartwychwstania Chrystusa z przyjściem i działaniem Parakleta w mowie pożegnalnej (por. J 16,7) należy okres po zmartwychwstaniu Jezusa pojmować niewątpliwie jako okres obecności i działania Parakleta. W świetle czwartej Ewangelii moment zmartwychwstania Chrystusa jest kluczowy i stanowi linię demarkacyjną dla pamięci uczniów. Autor Ewangelii nie uściśla, kiedy owo przypomnienie nastąpiło (w jakim odstępie czasu po zmartwychwstaniu). Ważne jest samo wydarzenie rezurekcji. W świetle koncepcji pamięci społecznej ten fakt ma ogromne znaczenie. To nie śmierć, jako moment „zerwania”, ale właśnie zmartwychwstanie (a więc przezwyciężenie tego „zerwania”) jest katalizatorem pamięci. Doświadczenie zmartwychwstania jest czymś, czego teoria pamięci społecznej, jako koncepcja ukształtowana na polu nauk społecznych, nie jest w stanie uchwycić.

Jednak zgodnie z podstawowymi założeniami tej koncepcji, pamięć wspólnoty uczniów nie tkwi w przeszłości, ale jest aktualizowana w świetle ich obecnego przeżywania oraz potrzeb. To, na czym polega aktualizacja oraz pogłębienie pamięci uczniów, czytelnik miał możliwość odkrywać w trakcie wcześniej przedstawionych analiz egzegetycznych.

\section{Konkluzja}

Motyw pamięci jest w narracji czwartej Ewangelii, skupiającej się głównie na wydarzeniach przedpaschalnych, bardzo ważnym elementem doświadczenia Kościoła popaschalnego. Pamięć ta w sytuacji popaschalnej jest niezmiernie istotnym łącznikiem pomiędzy Jezusem historii i Chrystusem wiary. Dzięki tej pamięci osoba Jezusa i Jego objawienie nie zamilkły, nie zostały zamknięte w przeszłości, ale są ciągle obecne w teraźniejszości Jego ucznia. Treścią pamięci są słowa Pisma oraz słowa Jezusa, a więc Objawienie zapisane w księdze Ewangelii. Jak widać, pamięć ta jest pamięcią aktualizującą, twórczą. Podstawowym sprawcą jej kreatywności jest Para- 
klet - Duch Święty. Przypominanie, którego dokonuje Paraklet, jest bardzo ważnym działaniem w procesie Objawienia, ma ono charakter historyczny, aktualizujący oraz aplikujący. Działalność Ducha łączy współczesność popaschalnego Kościoła z przeszłością ziemskiego Jezusa. Duch jest gwarantem tego, że osoba i historia Jezusa nie zgubią się w coraz bardziej oddalającej się przeszłości, lecz zostaną na zawsze teraźniejszością Kościoła, teraźniejszością człowieka wierzącego. Dzięki mocy Ducha uczeń może doświadczać Objawienia Jezusa hic et nunc i odpowiedzieć na to Objawienie postawą wiary. Bardzo ważnym wymiarem ożywianej przez Parakleta pamięci Kościoła jest fakt, iż pełni ona swoją funkcję w konkretnej egzystencjalnej sytuacji wierzących. Dla wspólnoty w czwartej Ewangelii tą sytuacją egzystencjalną jest poszukiwanie nowej tożsamości ucznia zarówno w sytuacji nieobecności Mistrza, jak i prześladowania oraz konfliktu z synagogą.

\section{Bibliografia}

Almášiová, A., Sociológia (Ružomberok: Verbum 2012).

Assmann, A., Erinnerungsräume: Formen und Wandlungen des kulturellen Gedächtnisses (München: Beck 2018).

Assmann, J., „Das kulturelle Gedächtnis”, Erwägen, Wissen, Ethik 13 (2002) 239-247.

Assmann, J., Pamięć kulturowa: pismo, zapamiętywanie i polityczna tożsamość w cywilizacjach starożytnych (Warszawa: Wydawnictwo UW 2008).

Assmann, J., Religion und kulturelles Gedächtnis: Zehn Studien, wyd. 3 (München: Beck 2007).

Bartels, K.H. - Brown, C., „Remember, remembrance”, The New International Dictionary of New Testament Theology, wyd. 6 (red. C. Brown) (Grand Rapids, MI: Zondervan - Devon, UK: Paternoster 1981) III, 230-247.

Beutler, J., Das Johannesevangelium: Kommentar (Freiburg - Basel - Wien: Herder 2013).

Blair, E.P., „An Appeal to Remembrance: The Memory Motif in Deuteronomy”, Interpretation: A Journal of Bible and Theology 15/1 (1961) 41-47.

Blenkinsopp, J., „Memory, Tradition, and the Construction of the Past in Ancient Israel”, Biblical Theology Bulletin 27/3 (1997), 76-82.

Bonnard, P., „Lanamnèse, structure fondamentale de la théologie du Nouveau Testament”, Cahiers de la Revue de théologie et de philosophie 3 (1980) 1-11.

Bradshaw, A.E., „The Eucharistic Memory of Jesus' Words in First Corinthians”, Harvard Theological Review 90/4 (1997) 359-370.

Braulik, G., „Das Deuteronomium und die Gedächtniskultur Israels: Redaktionsgeschichtliche Beobachtungen zur Verwendung von למד", Biblische Theologie und gesellschaftlicher Wandel: Für Norbert Lohfink (red. G. Braulik - W. Gross - S. McEvenue) (Freiburg: Herder 1993) 9-31.

Brown, R.E., The Gospel According to John, I-XII: Introduction, Translation, and Notes (Anchor Bible 29a; New York: Doubleday 1966). 


\section{BRANISLAV KLUSKA}

Brown, R.E., The Gospel According to John, XIII-XXI: Introduction, Translation, and Notes (Anchor Bible 29b; New York: Doubleday 1970).

Brown, T.G., Spirit in the Writings of John: Johannine Pneumatology in Social-Scientific Perspective (London - New York: Clark 2004).

Byrskog, S., „A New Quest for the Sitz Im Leben: Social Memory, the Jesus Tradition and the Gospel of Matthew", New Testament Studies 52/3 (2006) 319-336.

Culpepper, R.A., Anatomy of the Fourth Gospel: A Study in Literary Design (Philadelphia, PA: Fortress 1987).

Dąbek, T.M., „Przywołany - Posłany - Obecny. Bogactwo misji Ducha Parakleta obecnego wśród uczniów Jezusa na podstawie J 14-16”, Ruch Biblijny i Liturgiczny 60/1 (2007) 17-28.

Eckstein, H.J., „Das Johannesevangelium als Erinnerung an die Zukunft der Vergangenheit: Gegenwärtiges Erinnern und modalisierte Zeit", Memory in the Bible and Antiquity, The Fifth Durham-Tübingen Research Symposium (Durham, September 2004) (red. S.C. Barton - L.T. Stuckenbruck - B.G. Wold) (WUNT 212; Tübingen: Mohr Siebeck 2007) 299-319.

Eising, H., ,zākhar, zēkher, zikkārôn, 'azk'ārāh”, Theological Dictionary of the Old Testament (red. J.G. Botterweck - H. Ringgren) (Grand Rapids, MI: Eerdmans 1980) IV, 64-82.

Eve, E., „Memory, Orality and the Synoptic Problem”, Early Christianity 6/3 (2015) 311-333.

Feník, J., „Ježišova telesnost' v Jánovom evanjeliu”, Verba Theologica 18/1 (2019) 74-85.

Ferraro, G., Il Paraclito, Cristo, il Padre nel quarto vangelo (Città del Vaticano: Libreria Editrice Vaticana 1996).

Foster, P., „Memory, Orality, and the Fourth Gospel: Three Dead-Ends in Historical Jesus Research", Journal for the Study of the Historical Jesus 10/3 (2012) 191-227.

Frey, J., „The Gospel of John as a Narrative Memory of Jesus”, Memory and Memories in Early Christianity: Proceedings of the International Conference Held at the Universities of Geneva and Lausanne (June 2-3, 2016) (red. S. Butticaz - E. Norelli) (WUNT 398; Tübingen: Mohr Siebeck 2018) 261-284.

Gärtner, J., „From Generation to Generation: Remembered History in Psalm 78”, Remembering and Forgetting in Early Second Temple Judah (red. E. Ben Zvi - C. Levin) (FAT 85; Tübingen: Mohr Siebeck 2012) 269-278.

Gnilka, J., Johannesevangelium (Die Neue Echter Bibel: Kommentar zum Neuen Testament mit der Einheitsübersetzung 4; Würzburg: Echter 1983).

Gregory, A., „Memory as Method: Some Observations on Two Recent Accounts”, Journal for the Study of the Historical Jesus 16/1 (2018) 52-61.

Guijarro, S., „Cultural Memory and Group Identity in Q”, Biblical Theology Bulletin 37/3 (2007) 90-100.

Halbwachs, M., La Topographie légendaire des évangiles en terre sainte: étude de mémoire collective (Paris: Presses Universitaires de France 1942).

Halbwachs, M., Le mémoire collective (Paris: Presses Universitaires de France 1950).

Halbwachs, M., Les cadres sociaux de la mémoire (Paris: Arno 1952).

Halbwachs, M., Społeczne ramy pamięci, wyd. 2 (Warszawa: PWN 2008).

Hendel, R., „The Exodus in Biblical Memory”, Journal of Biblical Literature 120/4 (2001) 601-622.

Hroboň, B. (red.), Žalmy 51 - 75 (Komentáre k Starému zákonu 5; Trnava: Dobrá kniha 2017). 
Hübenthal, S., „Social and Cultural Memory in Biblical Exegesis”, Cultural Memory in Biblical Exegesis (red. P. Carstens - T. Hasselbalch - N.P. Lemche) (Perspectives on Hebrew Scriptures and its Contexts; Piscataway, NJ: Gorgias Press 2012) 175-199. https://doi. org/10.31826/9781463234690

Jan Paweł II, Encyklika „Dominum et Vivificantem” Ojca Świętego Jana Pawła II o Duchu Świętym w życiu Kościoła i świata (Wrocław: TUM 1998).

Jankowski, A., „Paraklet: geneza i znaczenie terminu”, Egzegeza Ewangelii Św. Jana: Kluczowe teksty i tematy teologiczne, wyd. 2 (red. F. Gryglewicz) (Lublin: Wydawnictwo KUL 1992) 183-206.

Keener, C. S., The Gospel of John: A Commentary (Peabody, MA: Hendrickson 2003) II.

Keith, C., „Memory and Authenticity: Jesus Tradition and What Really Happened”, Zeitschrift für die neutestamentliche Wissenschaft und die Kunde der älteren Kirche 102/2 (2011) 155-177.

Keith, C., „Social Memory Theory and Gospels Research: The First Decade (Part One)”, Early Christianity 6/3 (2015) 354-376.

Keith, C., „The Narratives of the Gospels and the Historical Jesus: Current Debates, Prior Debates and the Goal of Historical Jesus Research", Journal for the Study of the New Testament 38/4 (2016) 426-455.

Kirk, A., „Jesus Tradition as Social Memory”, Memory, Tradition and Text: Uses of the Past in Early Christianity (red. T. Thatcher) (SemeiaSt 52; Atlanta, GA: Society of Biblical Literature 2005) 25-42.

Kluska, B., Uczeń ikona Chrystusa: Studium egzegetyczno-teologiczne Mowy pożegnalnej J 13,31-16,33 (Studia Biblica Lublinensia 3; Lublin: Wydawnictwo KUL 2007).

Klusková, M., „Prawda o Bogu i Jego planie dla Izraela w Ps 105 i 106”, The Biblical Annals 7/2 (2017) 207-233.

Kot, P., „Popaschalne świadectwo Parakleta o sądzie Boga nad «światem» w ujęciu J 16, 8-11”, Verbum Vitae 26 (2014) 71-93.

Kowalski, M., „Retoryka i socjo-retoryka w lekturze tekstów Nowego Testamentu, Cz. 2: Socjo-retoryka - projekt holistycznej lektury tekstu", The Biblical Annals 7/1 (2017) 107-147.

Kubiś, A., The Book of Zechariah in the Gospel of John (Pendé: Gabalda 2012).

Kudasiewicz, J., „Pamięć w Biblii”, W Drodze 344 (2002) 40-53.

Le Donne, A., „Memory, Commemoration and History in John 2:19-22: A Critique and Application of Social Memory", The Fourth Gospel in First-Century Media Culture (red. A. Le Donne - T. Thatcher) (LNTS 426; London: Clark 2011) 186-204.

Lapko, R. (red.), Jánovo evanjelium: Nový preklad a krátky komentár (Bratislava: Veda 2019).

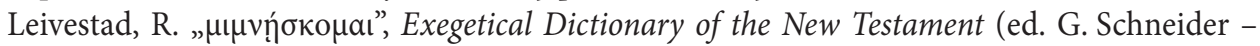
H. Balz) (Grand Rapids, MI: Eerdmans 1990) II, 430-431.

Malina, B.J. - Rohrbaugh, R.L., Social-Science Commentary on the Gospel of John (Minneapolis, MN: Fortress 1998).

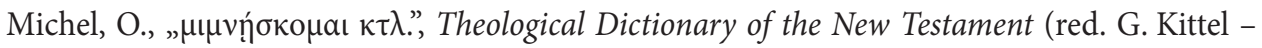
G. Friedrich - G.W. Bromiley) (Grand Rapids, MI: Eerdmans 1971) IV, 675-83.

Mlakuzhyil, G., The Christocentric Literary Structure of the Fourth Gospel, wyd. 2 (Analecta Biblica 117; Roma: Gregorian \& Biblical Press 2011).

Moloney, F.J., Belief in the Word: Reading John 1-4 (Minneapolis, MN: Fortress 1993). 


\section{BRANISLAV KLUSKA}

Painter, J., „The Farewell Discourses and the History of Johannine Christianity”, New Testament Studies 27/4 (1981) 525-543.

Pavan, M., He Remembered That They Were but Flesh, a Breath That Passes and Does Not Return (Ps 78-39): The Theme of Memory and Forgetting in the Third Book of the Psalter (Pss 73-89; New York: Lang 2014).

Pavan, M., „La memoria nel Salmo 77”, Rivista Biblica 60/1 (2012) 69-90.

Pikor, W., „Rola pamięci w decyzjach moralnych człowieka w świetle Księgi Ezechiela”, Moralność objawiona w Biblii (red. W. Pikor) (Analecta Biblica Lublinensia 7; Lublin: Wydawnictwo KUL 2011) 81-98.

Popović, A., „The Bible as a Book of Memory”, Antonianum 79/3 (2004) 411-443.

Popowski, R., Wielki słownik grecko-polski Nowego Testamentu: wydanie z pełna lokalizacja greckich haset, kluczem polsko-greckim oraz indeksem form czasownikowych, wyd. 3 (Warszawa: Vocatio 1997).

Rajewski, A., „Rozważania na temat Assmanowskiej teorii pamięci”, Rocznik Antropologii Historii 3/1 (2013) 187-202.

Ravasi, G., Il libro dei salmi (Bologna: Dehoniane 1983) II.

Robbins, V.K., The Tapestry of Early Christian Discourse: Rhetoric, Society, and Ideology. (London: Routledge 1996).

Schenke, L., Johannes: Kommentar (Düsseldorf: Patmos 1998).

Schnackenburg, R., Das Johannesevangelium. III. Kommentar zu Kapitel 13-21, wyd. specjalne (Herders Theologischer Kommentar zum Neuen Testament 4/3; Freiburg - Basel - Wien: Herder 2000).

Schnelle, U., „Die Abschiedsreden im Johannesevangelium”, Zeitschrift für die neutestamentliche Wissenschaft und die Kunde der älteren Kirche 80/1-2 (1989) 64-79.

Scholtissek, K., „Abschied und neue Gegenwart: Exegetische und theologische Reflexionen zur johanneischen Abschiedsrede 13,31 - 17,26", Ephemerides Theologicae Lovanienses 75/4 (1999) 332-358.

Schröter, J., „Nicht nur eine Erinnerung, sondern eine narrative Vergegenwärtigung. Erwägungen zur Hermeneutik der Evangelienschreibung", Zeitschrift für Theologie und Kirche 108/2 (2011) 119-137.

Segovia, F.F., „The Structure, Tendenz, and Sitz im Leben of John 13:31-14:31”, Journal of Biblical Literature 104/3 (1985) 471-493.

Smith, M.S. „Remembering God: Collective Memory in Israelite Religion”, Catholic Biblical Quarterly 64/4 (2002) 631-651.

Smith, M.S. The Memoirs of God: History, Memory and the Experience of the Divine in Ancient Israel (Minneapolis, MN: Fortress 2004).

Thatcher, T., „John's Memory Theater: The Fourth Gospel and Ancient Mnemo-Rhetoric”, The Catholic Biblical Quarterly 69/3 (2007) 487-505.

Thatcher, T., Why John Wrote a Gospel: Jesus - Memory - History (Eugene, OR: Wipf and Stock 2012).

Tillmann, N., „Das Wasser bis zum Hals!”: Gestalt, Geschichte und Theologie des 69. Psalms (Altenberge: Oros 1993).

Trstenský, F., Svet Nového zákona (Svit: Katolícke biblické dielo 2008). 
Vouga, F., „Erinnerung an Jesus im Johannesevangelium”, Zeitschrift für Neues Testament 10/2 (2007) 28-37.

Wengst, K., Das Johannesevangelium: Kapitel 1-10, wyd. 2 (Theologischer Kommentar zum Neuen Testament 4; Stuttgart: Kohlhammer 2004).

Wilson, B.R., Magic and the Millennium: A Sociological Study of Religious Movements of Protest among Tribal and Third-World Peoples (New York: Harper \& Row 1973).

Wischermann, C., „Geschichte als Wissen, Gedächtnis oder Erinnerung? Bedeutsamkeit und Sinnlosigkeit in Vergangenheitskonzeptionen der Wissenschaften vom Menschen". Die Legitimität der Erinnerung und die Geschichtswissenschaft (red. C. Wischermann) (Wiesbaden: Steiner 1996) 55-85.

Witczyk, H., „Paraklet duchem Nowego Przymierza (J 14,15-17)”, Roczniki Teologiczne 46/1 (1999) 77-91.

Wróbel, M., „Historia i teologia czwartej ewangelii w świetle «Żydów» Janowych”, Colloquia Theologica Ottoniana 1 (2018) 107-145.

Zenger, E., „Lieder der Gotteserinnerung. Psalm 137 im Kontext seiner Nachbarpsalmen”, Für alle Zeiten zur Erinnerung (Jos 4,7): Beiträge zu einer biblischen Gedächtniskultur (red. M. Theobald - R. Hoppe) (SBS 209; Stuttgart: Katholisches Bibelwerk 2006) 55-85. 
